\title{
A Proposal for a $100 \%$ Use of Bauxite Residue Towards Inorganic Polymer Mortar
}

\author{
Tobias Hertel $^{1}$ (D) Bart Blanpain $^{1} \cdot$ Yiannis Pontikes $^{1}$
}

Published online: 5 August 2016

(C) The Minerals, Metals \& Materials Society (TMS) 2016

\begin{abstract}
A new process is suggested in the present work turning bauxite residue (BR) into a ready-made mortar for the synthesis of inorganic polymers, effectively transforming the Bayer process into a zero-waste process. This was achieved by firing $\mathrm{BR}$ at $1100{ }^{\circ} \mathrm{C}$ which supports the formation of liquid phase and results after subsequent fast cooling in a semivitreous material. Based on thermodynamic calculations, the process was subsequently improved by adding minor quantities of $\mathrm{C}$ and silica to BR before firing which leads to the carbothermic reduction of ferric iron into ferrous iron; the new blends demonstrated an increase in the melt formation and eventually in the content of amorphous phase after solidification. The resulting material was activated using a $\mathrm{K}$-silicate solution and was cured at $60{ }^{\circ} \mathrm{C}$ for $72 \mathrm{~h}$. The synthesized materials were water insoluble and dense, demonstrating compressive strength exceeding $40 \mathrm{MPa}$ for the silica-rich blend. These inorganic polymers can find applications in construction, such as pavement tiles or floor/roofing tiles. A possible implementation of the process to transform BR within the alumina refinery is also represented.
\end{abstract}

Keywords Bauxite residue - Inorganic polymer . Geopolymers · Valorization $\cdot$ Zero-waste

The contributing editor for this article was D. Panias.

Tobias Hertel

tobias.hertel@kuleuven.be

1 Department of Materials Engineering, KU Leuven, Kasteelpark Arenberg 44, 3001 Heverlee, Belgium

\section{Introduction}

Within the Bayer cycle, the alumina production out of bauxite creates voluminous amounts of the insoluble digestion by-product bauxite residue (BR), also called red mud. Per ton of produced alumina, about 1-1.5 tons of bauxite residue is generated [1]. Estimations assume that the global inventory of BR reached about $2.7 \mathrm{Gt}$ in 2007 with an increasing trend of more than $120 \mathrm{Mt}$ per year [2]. According to the composition of the parent bauxite and technology applied for processing, the derived $\mathrm{BR}$ consists mainly of different quantities of $\mathrm{Fe}_{2} \mathrm{O}_{3}, \mathrm{Al}_{2} \mathrm{O}_{3}, \mathrm{SiO}_{2}, \mathrm{TiO}_{2}$, $\mathrm{CaO}$, and $\mathrm{Na}_{2} \mathrm{O}$. An overview of the compositional range of $\mathrm{BR}$ is listed elsewhere [3].

The high alkalinity is considered to be one of the principal reasons for the limited success until today in finding applications for BR. Increasing awareness has led to a multitude of research projects related to the reuse of BR as a raw material for different industrial applications, like ceramics [4], but also as a source for the recovery of base and minor metals [5-7]. An application in building materials, as a component in cements, filler material, or geopolymers, seems to be a straightforward approach in terms of high quantity reuse [8].

Generally, the use of geopolymer as an alternative binder drew the attention because of its excellent properties, such as high compressive strength, resistance to acidic solutions, and thermal stability [9-12], in combination with their lower $\mathrm{CO}_{2}$ footprint $[13,14]$. The term geopolymer was introduced by Davidovits in 1970s, who defined a geopolymer as an Al- and Si-rich cementitious, amorphous binder, which is formed by polymerization of an alkaliactivated solid aluminosilicate precursor [15]. It consists of chains or a $3 \mathrm{D}$ framework of linked $\mathrm{AlO}_{4}{ }^{5-}$ and $\mathrm{SiO}_{4}{ }^{4-}$ tetrahedra. The more general term inorganic polymer (IP) 
defines a supergroup with a deviation from the tetrahedral coordination of $\mathrm{Al}$ and $\mathrm{Si}$ and the aluminosilicate chemistry [16].

In terms of research in the domain of inorganic polymers and BR, a substantial quantity of work is being done in incorporating bauxite residue in solid blends with a highly reactive precursor material. Compressive strengths of 20.5 MPa were, for instance, reached in metakaolin-based IP with additions of $15 \mathrm{wt} \%$ BR [17]. A new type of composite geopolymers with the maximum compressive strengths of 20.5 MPa was presented by He et al. [18] using red mud in combination with rice husk (BR/rice husk weight ratio 0.5 ) and $\mathrm{NaOH}$ solution for the synthesis. In view of the highly amorphous character and hence the high reactivity of the silica source, rice husk ash, the addition of sodium silicate was not necessary. Ye et al. [19] mixed ground-granulated blast furnace slag (GGBFS) in varying proportions with calcined $\mathrm{BR}\left(800^{\circ} \mathrm{C}\right)$, reaching, for instance, $50 \mathrm{MPa}$ after 28 days in a 50-50 wt \% mix. Foamed BR-based geopolymers were synthesized by Badanoiu et al. [20] using up to $25 \mathrm{wt} \%$ bauxite residue in combination with waste glass in the solid mix and the filtrate of red mud slurry and $\mathrm{NaOH}$ solution, respectively, as liquid component. All of these described inorganic polymers are characterized by a significant decrease in compressive strength with an increasing content of bauxite residue.

A second group of studies revolves around thermally treated BR. In the work of Ke et al. [21], one-part binders were developed after calcination of (dry) bauxite residue with $5-15 \mathrm{wt} \% \mathrm{Na}_{2} \mathrm{O}$ at $800{ }^{\circ} \mathrm{C}$, probably in air. This alkali treatment resulted in the formation of hydraulic phases, disordered peralkaline aluminosilicate, $\mathrm{C}_{3} \mathrm{~A}$, and $\alpha_{\mathrm{L}}-\mathrm{C}_{2} \mathrm{~S}$. Maximum strengths up to $10 \mathrm{MPa}$ were achieved after 7 days with $10 \mathrm{wt} \% \mathrm{NaOH}$ addition which dramatically decreased after 3 weeks of curing. In another work, Hairi et al. [22] used raw and calcined bauxite residue as the main component for IP, with varying contents of amorphous silica fume (6-26 wt \%) and alumina (0-20 wt \%) in the solid mix and a sodium silicate solution as an activator. The highest compressive strength of $58 \mathrm{MPa}$ was reported for a mix of $83 \mathrm{wt} \%$ of thermally pretreated $\left(500{ }^{\circ} \mathrm{C}\right) \mathrm{BR}$, combined with $17 \mathrm{wt} \%$ silica fume and a sodium silicate activating solution at a solution-to-solid ratio of 0.5 .

Other iron-rich precursor materials, for example copper [23], lead [24], or ferro-nickel slags [25, 26], have shown already a potential for the synthesis of inorganic polymers and the reuse of industrial wastes. Characteristics include, among others, a partially vitrified structure and ferrous iron [27]. Chemically considered, these slags do not differ significantly from BR, apart from the mineralogy and the oxidation state of iron. This leads to the assumption that a chemical and thermal adaptation can turn BR into a suitable precursor for IP.
The first milestone in this trajectory is to create a precursor with a substantial amount of amorphous phase at room temperature, assuming that this would be prone to dissolution by alkali addition. If that is possible, the downstream use toward applications becomes straightforward. It has already been demonstrated that in ceramics made of BR reducing conditions promote liquid phase formation [4]. This takes place preferentially in the interface between BR and quartz grains [5] in view of the locally established eutectics. The chemistry of BR is in fact located in the $\mathrm{FeO}-\mathrm{Al}_{2} \mathrm{O}_{3}-\mathrm{CaO}-\mathrm{SiO}_{2}$ domain and semivitreous precursors can be formed from such compositions that are prone to form inorganic polymers $[23,27]$.

In this study, a thermal and chemical modification of BR was performed to transform it into a suitable precursor for the synthesis of inorganic binders. Based on thermodynamic calculations, three different mix designs with different amounts of bauxite residue, carbon, and silica were analyzed. Carbon was used for the carbothermic reduction of $\mathrm{Fe}^{3+}$ into $\mathrm{Fe}^{2+}$, which promotes the formation of liquid phase during a heat treatment. Additional silica further increases the formation of liquid phase. Fast cooling was applied to prevent the crystallization during solidification. The obtained precursor materials were activated to produce inorganic polymers, which were investigated using microanalysis and FTIR. The flexural and compressive strengths were also analyzed. We conclude with a suggestion on how the process can be industrialized, even within an alumina plant.

\section{Experimental Work}

\section{Characterization of BR}

Filter-pressed bauxite residue cake, received from Aluminium of Greece (AoG), Greece, was used as a raw material in the experiments. The residual moisture of the as-produced BR cake was around $28 \mathrm{wt} \%$, thus drying was carried out at $80{ }^{\circ} \mathrm{C}$ for $24 \mathrm{~h}$ in a laboratory oven before determination of the chemical and mineralogical composition. A porcelain mortar was used to break down aggregates and to grind BR into a fine powder.

The chemical composition was determined using a PW 2400 (Phillips) automatic sequential wavelength-dispersive $\mathrm{X}$-ray fluorescence spectrometer and the software Uniquant 5. X-ray diffractograms were recorded for the investigation of the mineralogical composition using a Phillips type PW 1830 diffractometer. For quantification, $10 \mathrm{wt} \%$ of analytical-grade crystalline $\mathrm{ZnO}$ was added to $\mathrm{BR}$ as an internal standard material. The blend was milled for $7.5 \mathrm{~min}$ in a McCrone micronizing mill using ethanol 
(purity $99.9 \%$ ) as a grinding agent and corundum grinding elements to assure an adequate fineness for analysis. Diffractograms were recorded in the measurement range of $10^{\circ}-70^{\circ} 2 \vartheta$ using $\mathrm{CuK} \alpha$ radiation applying an acceleration voltage of $45 \mathrm{kV}$, a current of $30 \mathrm{~mA}$, a step size of $0.020^{\circ}$, and a counting time of $2.5 \mathrm{~s}$ per step. The obtained data were evaluated with EVA V.3.1 (Bruker AXS) and quantified with Topas-Academic V.5 [28], using the Rietveld method in combination with the fundamental parameter approach. Structural data were taken from the ICSD database [29].

\section{Thermodynamic Calculations}

The thermodynamic software package FactSage V.6.4 [30] (using FactPS, FTOxid, and FSstel databases) was used to provide data for suitable mix designs. Using the obtained XRF data of BR as the starting point, the additions of varying amounts of carbon and silica were simulated for a temperature of $1100{ }^{\circ} \mathrm{C}$ with the main focus on the maximization of liquid phase in a modified bauxite residue system. $\mathrm{CaO}$ additions were also simulated, but in comparison to $\mathrm{SiO}_{2}$, higher additions would have been necessary to get comparable amounts of liquid phase formation. The temperature of $1100{ }^{\circ} \mathrm{C}$ was chosen as a compromise between promoting the amount of liquid phase and simulating a realistic scenario for industrial applications. An open system was applied to model the continuous escape of forming gas species during the heat treatment.

\section{Preparation and Heat Treatment of BR Mixes}

Three different sample compositions consisting of varying amounts of BR, carbon (graphite powder, AlfaAesar, purity $99.9 \%$ ), and silica (microcrystalline silica, AlfaAesar, purity $99.5 \%$ ) were prepared and mixed in ethanol (purity $99.9 \%)$ with $\mathrm{Al}_{2} \mathrm{O}_{3}(\varnothing 10 \mathrm{~mm})$ milling balls using a Turbula shaker (WAB, Switzerland) for $15 \mathrm{~h}$ to guarantee homogeneous mixing. The alcohol was removed subsequently using a rotary evaporator.

The prepared samples were fired for $1 \mathrm{~h}$ at a maximum temperature of $1100 \pm 10{ }^{\circ} \mathrm{C}$ in a custom-made iron crucible, using an induction furnace (type TF 4000, Indutherm $\mathrm{GmbH}$, Germany). To prevent oxidation and to assure a homogeneous temperature gradient in the crucible, a lid with integrated gas inlet and outlet tubes was screwed on top of the crucible. The atmosphere was kept inert by continuously flushing Ar gas (30 1/h). After removing the crucible from the furnace, the lid was removed and the heat-treated material was air-quenched by blowing compressed air with an air gun directly into the crucible, in order to get a semivitreous solidified material.

\section{Characterization of Precursors}

After removing from the crucible, the obtained precursor materials were initially ground in a disk mill (Retsch DM 200) followed by milling in a vibration disk mill (Retsch RS200) for $12 \mathrm{~min}$. The specific surface area and the particle size distribution of the precursor were determined using the Blaine method according to EN 196 and granulometric analysis using a Mastersizer 2000 (Malvern Instruments Ltd.), respectively. XRD analysis was carried out as described in "Characterization of BR" section. For structural characterization, attenuated total reflectance Fourier transform infrared spectroscopy (ATR-FTIR) was applied using a VERTEX 70 spectrometer (Bruker AXS). Spectra were collected in a range of $4500-400 \mathrm{~cm}^{-1}$ with a resolution of $4 \mathrm{~cm}^{-1}$ and 64 scans per single measurement.

\section{Synthesis and Characterization of Inorganic Polymers}

Inorganic polymers were prepared by activating the precursors using a ready-made, commercially available potassium silicate solution with the molar ratios of $\mathrm{SiO}_{2} /$ $\mathrm{K}_{2} \mathrm{O}=1.6$ and $\mathrm{H}_{2} \mathrm{O} / \mathrm{K}_{2} \mathrm{O}=16$ and an activating solutionto-precursor ratio of 0.25 . The commercial activation solution was chosen for evaluating the posed hypothesis of forming IP from modified BR. In a closer-to-real-life industrial process, sodium-based activators need to be used. For compressive and flexural strength testing, the activated precursors were cast into rectangular molds $\left(20 \times 20 \times 80 \mathrm{~mm}^{3}\right)$, and for the analysis of the microstructure, pastes were filled into molds with nearly cubic dimensions $\left(25 \times 25 \times 20 \mathrm{~mm}^{3}\right)$. Samples were wrapped and sealed with polymer foil in order to prevent evaporation of water. Curing was conducted for $72 \mathrm{~h}$ at an elevated temperature of $60{ }^{\circ} \mathrm{C}$ in a laboratory oven. After demolding, the specimens were cut with a low-speed saw into smaller pieces for assessing potential dissolution in water and for microanalysis. The stability in water of the synthesized materials was tested by immersing the samples in water for 7 days at $60{ }^{\circ} \mathrm{C}$; all synthesized materials were water insoluble. The microstructure of the IP was analyzed on BSE and SE images, using an XL30 FEG (Philips) scanning electron microscope. For this purpose, the cut samples were embedded in resin, ground with grinding paper, and polished with cloth and diamond paste $(3 \mu \mathrm{m})$. For assuring conductivity, the samples were coated with a thin platinum layer $(5 \mathrm{~nm})$. Electron microprobe analysis (JEOL JXA-8530F, operating at $15 \mathrm{kV}$ and $15 \mathrm{nA}$ ) was conducted to determine the chemical composition of the binder matrix and the aggregate minerals. As standards, plagioclase for $\mathrm{Al}_{2} \mathrm{O}_{3}, \mathrm{SiO}_{2}, \mathrm{Na}_{2} \mathrm{O}$, and $\mathrm{CaO}$, biotite for $\mathrm{K}_{2} \mathrm{O}$, and benitoite for $\mathrm{TiO}_{2}$ were selected. For 
determination of the iron content, the standards magnetite, metallic iron, pyrite, or hematite were selected. The use of the appropriate standard depends mainly on a similar density and content of the investigated oxide in the standard and the analyzed grain. A fast screening by EDX was therefore performed to choose a suitable standard. Uniaxial compressive and three-point bending flexural strength tests were conducted 3 days after synthesis using an Instron $5985(250 \mathrm{kN})$ testing machine, applying a crosshead speed of $2 \mathrm{~mm} / \mathrm{min}$ for the compressive tests and $3 \mathrm{~mm} /$ min for the flexural tests. FTIR measurements were carried out on ground inorganic polymer powders to compare the precursor materials and synthesized IP.

\section{Results and Discussion}

\section{Characterization of BR}

$\mathrm{X}$-ray fluorescence data show that the chemical composition of BR predominantly consists of $\mathrm{Fe}_{2} \mathrm{O}_{3}$ followed by $\mathrm{Al}_{2} \mathrm{O}_{3}, \mathrm{CaO}, \mathrm{SiO}_{2}$, and minor quantities of $\mathrm{TiO}_{2}$ and $\mathrm{Na}_{2} \mathrm{O}$ (Table 1).

Table 2 provides the quantification of the present mineralogical phases in BR.

\section{Thermodynamic Calculations With FactSage}

For the thermodynamic calculations, XRF data given in Table 1 were used as input to predict the ideal mineralogy at the investigated temperature of $1100{ }^{\circ} \mathrm{C}$. The development of liquid phase during heat treatment was investigated by modeling carbon and silica additions in mixes with bauxite residue. Figure 1a displays the evolution of phases by replacing BR with up to $2.4 \mathrm{wt} \%$ carbon.

With the reduction of present iron phases into bivalent $\mathrm{Fe}$, the increasing carbon content in the mix promotes the formation of liquid phase until approximately $1.65 \mathrm{wt} \% \mathrm{C}$ content in the mix. A maximum quantity of $36 \mathrm{wt} \%$ of liquid phase emerges in a mix of $98.4 \mathrm{wt} \% \mathrm{BR}$ and $1.6 \mathrm{wt} \%$ of $\mathrm{C}$, reflecting a BR/C weight ratio of 61.5. Spinels, perovskite, and wüstite are the expected crystalline phases at equilibrium conditions. The beforehand mentioned ratio of $\mathrm{BR} / \mathrm{C}$ of 61.5 is kept constant in Fig. $1 \mathrm{~b}$ where a varying content of $\mathrm{SiO}_{2}$ is modeled additionally in a three-component mix. The rising amount of silica leads to the further

Table 1 Normalized chemical composition of BR, based on XRF data (relative error of semiquantitative analysis: $10 \%$ )

\begin{tabular}{llllllll}
\hline Component & $\mathrm{Fe}_{2} \mathrm{O}_{3}$ & $\mathrm{Al}_{2} \mathrm{O}_{3}$ & $\mathrm{CaO}$ & $\mathrm{SiO}_{2}$ & $\mathrm{TiO}_{2}$ & $\mathrm{Na}_{2} \mathrm{O}$ & Others \\
\hline $\mathrm{wt} \%$ & 48 & 19 & 11 & 10 & 7 & 4 & $<1$ \\
\hline
\end{tabular}

Table 2 Mineralogical composition of BR (estimated relative error: $10 \%)$

\begin{tabular}{llr}
\hline Phase & Chemical composition & wt $\%$ \\
\hline Ca-Al-silicate & $\mathrm{Ca}_{3} \mathrm{Al}_{2}\left(\mathrm{SiO}_{4}\right)_{3}$ & 3 \\
Calcite & $\mathrm{CaCO}_{3}$ & 7 \\
Cancrinite & $\mathrm{Na}_{6} \mathrm{Ca}_{2} \mathrm{Al}_{6} \mathrm{Si}_{6} \mathrm{O}_{24}\left(\mathrm{CO}_{3}\right)_{2} \cdot 2 \mathrm{H}_{2} \mathrm{O}$ & 8 \\
Diaspore & $\mathrm{AlO}(\mathrm{OH})$ & 14 \\
Gibbsite & $\mathrm{Al}(\mathrm{OH})_{3}$ & 5 \\
Goethite & $\mathrm{FeOOH}$ & 5 \\
Hematite & $\mathrm{Fe}_{2} \mathrm{O}_{3}$ & 38 \\
Quartz & $\mathrm{SiO}_{2}$ & 1 \\
Rutile & $\mathrm{TiO}_{2}$ & 3 \\
Hydrogrossular & $\mathrm{Ca}_{3} \mathrm{Al}_{2}\left(\mathrm{SiO}_{4}\right)_{3-\mathrm{x}}(\mathrm{OH})_{4 \mathrm{x}}$ & 6 \\
Amorphous/not detected & & 10 \\
\hline
\end{tabular}

formation of liquid phase up to a maximum of $58 \mathrm{wt} \%$, while wüstite and perovskite are consumed.

\section{Mixes}

Based on the obtained results of the thermodynamic calculations, different mixes consisting of dried BR, carbon (graphite powder), and silica (microcrystalline silica) were designed (Table 3).

Additions were chosen to compare the expected difference in quantity of glassy phase with the resulting properties of potential inorganic polymers. Industrially feasible additions were taken into account, thus common, easily available materials were added in minor quantities without using additional fluxes.

In Fig. 2, the interrelation of both components in a mix with BR, concerning the formation of liquid phase, is visualized. The analyzed mixes are indicated.

The predicted chemical compositions of the liquid phase at equilibrium conditions for the three investigated mixes are shown in Table 4.

\section{Characterization of Precursor}

The mineralogy of the three different precursors differs and also partially deviates from the modeled phase assemblage.

The results of the quantitative XRD analysis of the precursor materials are shown in Table 5 .

In accordance with the predictions of the thermodynamic calculations, the amount of amorphous phase is rising in the mixes from Pr_BR over Pr_BRC to Pr_BRCS. In comparison with the modeled quantity of liquid phase, a lower amount of amorphous phase is detected after cooling to ambient temperature. The liquid phase formation mainly takes place at grain interfaces where the composition is appropriate for this purpose. Since no homogenization is 
Fig. 1 Modeled mineralogy in wt $\%$ (y-axis) at $1100{ }^{\circ} \mathrm{C}$ in dependence of a carbon content in a mix with BR and $\mathbf{b}$ silica content for a fixed ratio of $\mathrm{BR} / \mathrm{C}$ (61.5) (a)

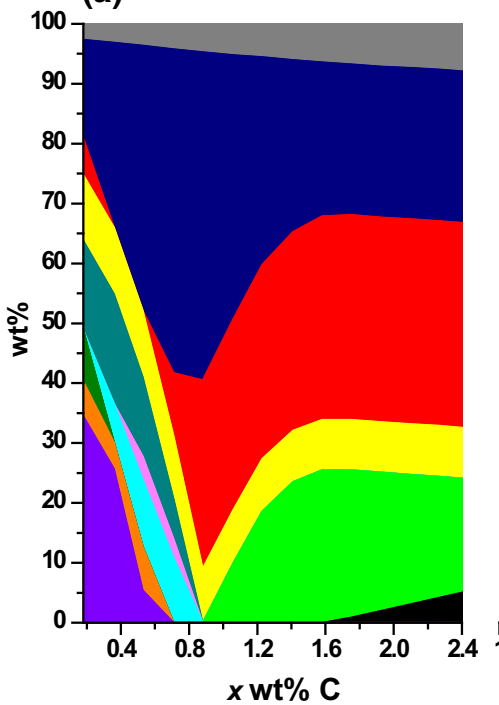

(b)

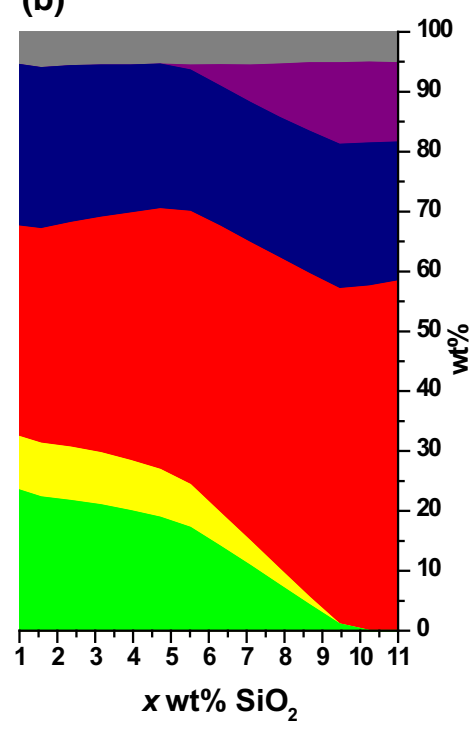

$\mathrm{Ca}(\mathrm{Al}, \mathrm{Fe}) \mathrm{O}_{10}$ $\mathrm{Ca}_{2}(\mathrm{Al}, \mathrm{Fe})_{8} \mathrm{SiO}_{16}$ $\mathrm{Al}_{2} \mathrm{O}_{3}$ Corundum $\mathrm{Fe}$ $\mathrm{FeO}$ $\mathrm{Ca}_{2} \mathrm{Al}_{2} \mathrm{SiO}_{7}$ Gehlenite Melilite group $\mathrm{NaAlO}$ $\mathrm{NaAISiO}_{4}$ Nepheline $\mathrm{CaTiO}_{3}$ Perovskite $\mathrm{Fe}_{3} \mathrm{O}_{4}-\mathrm{FeAl}_{2} \mathrm{O}_{4}$ Spinel solid solution Magnetite - Hercynite

$\mathrm{FeAl}_{2} \mathrm{O}_{4}-\mathrm{Fe}_{2} \mathrm{TiO}_{4}$ Spinel solid solution Hercynite - Ulvöspinel Liquid phase Gas
Table 3 Investigated precursor mixes

\begin{tabular}{lclc}
\hline Mix & $\mathrm{BR}(\mathrm{wt} \%)$ & $\mathrm{C}(\mathrm{wt} \%)$ & $\mathrm{SiO}_{2}(\mathrm{wt} \%)$ \\
\hline Pr_BR & 100.00 & 0 & 0 \\
Pr_BRC & 98.40 & 1.60 & 0 \\
Pr_BRCS & 88.56 & 1.44 & 10.00 \\
\hline
\end{tabular}

conducted during the firing (there is no full melt), this precondition for melt formation is not guaranteed everywhere in the bulk mix, resulting eventually in a lower degree of glass formation. Additionally, the air quenching cooling method provides time for crystallization during cooling. Other cooling methods like direct water quenching are currently under investigation.

Crystalline phases like spinel solid solutions are identified in all samples. The preexisting cancrinite (i.e., in the raw BR) transforms during heat treatment to nepheline, while the gehlenite formation can be explained possibly by hydrogrossular degradation and recrystallization [19, 31, 32]. These silicates are examples of mineral phases which were not predicted in the thermodynamic calculation for the given compositions, except for Pr_BR. These phases are assumed to be metastable due to the firing duration of $1 \mathrm{~h}$ which is not sufficient to reach equilibrium and for the same reasons
Fig. 2 Quantity of liquid phase at $1100{ }^{\circ} \mathrm{C}$ in dependence of silica and carbon contents in a blend with $\mathrm{BR}$. Wt\% $\mathrm{BR}=100-x(\mathrm{wt} \%$ $\left.\mathrm{SiO}_{2}\right)-y(\mathrm{wt} \% \mathrm{C})$. Analyzed mixes are indicated

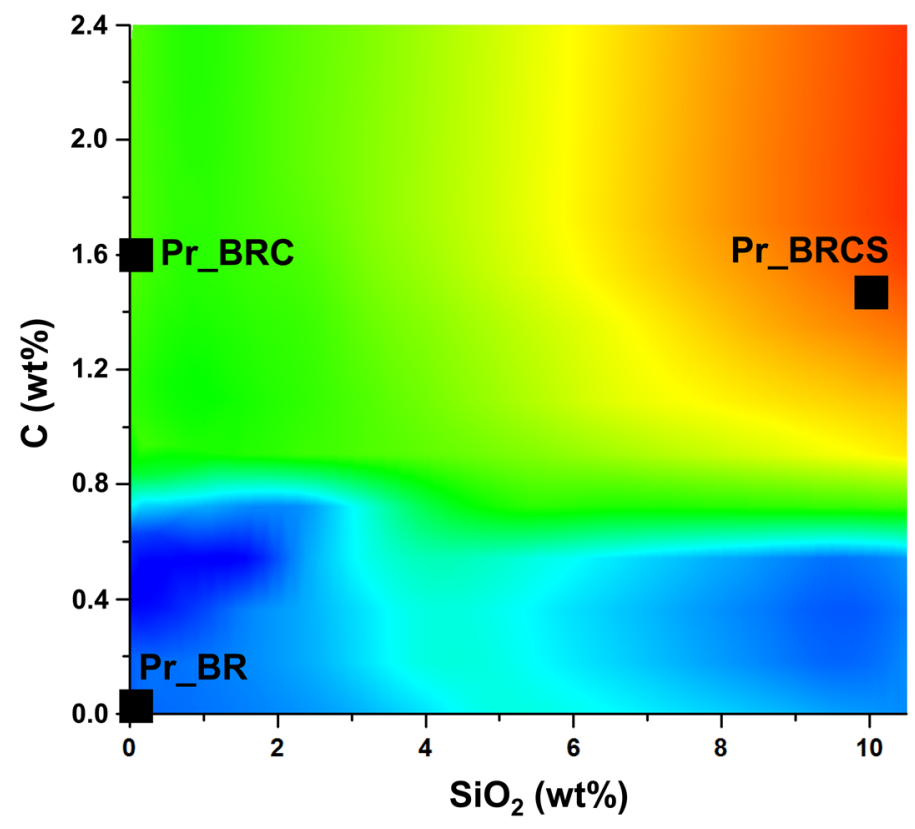


Table 4 Predicted chemistry of the liquid phases of the investigated precursor mixes

\begin{tabular}{lllc}
\hline Oxide & Pr_BR (wt\%) & Pr_BRC (wt\%) & Pr_BRCS (wt\%) \\
\hline $\mathrm{Na}_{2} \mathrm{O}$ & 12.0 & 11.1 & 5.9 \\
$\mathrm{Al}_{2} \mathrm{O}_{3}$ & 22.5 & 17.0 & 15.0 \\
$\mathrm{SiO}_{2}$ & 43.3 & 29.5 & 32.9 \\
$\mathrm{CaO}$ & 21.4 & 20.4 & 16.1 \\
$\mathrm{FeO}$ & 0 & 18.2 & 27.4 \\
$\mathrm{Fe}_{2} \mathrm{O}_{3}$ & 0.4 & 0.8 & 0.8 \\
$\mathrm{TiO}_{2}$ & 0.4 & 2.9 & 2.0 \\
\hline
\end{tabular}

discussed earlier. Not all minor oxides, like for instance $\mathrm{MgO}$ and $\mathrm{MnO}(<2 \mathrm{wt} \%)$, crystalline $\mathrm{H}_{2} \mathrm{O}$, and carbonates, could be considered in the thermodynamic calculations due to the high computing time of the software as a reason of the large number of oxides. Thus, their influence on the phase assemblage remains unclear. The formation of iron can be explained due to a possible local reduction of hematite to metallic iron, the influence of the crucible material either by local diffusion reactions or the impact of the mechanical removal of the precursor using a metal rod.

The three precursors, which were ground in the same way, show a similar particle size distribution and specific surface area, making a comparison of the reactivity possible (Table 6).

The recorded FTIR spectra for the precursors are shown in comparison with the synthesized IP in "IP from Fired BR" section.

\section{IP from Fired BR}

Three types of dense inorganic materials could be synthesized, which do not dissolve in deionized water. Consideration of the microstructure reveals the formation of an amorphous binder matrix in all three investigated samples (Fig. 3).

In accordance with the obtained XRD results, a multitude of different, partially idiomorphic crystalline phases can be observed in all samples. Considering the homogeneity and the porosity, differences in the synthesized binders can be observed. A rough surface and a high degree of grain pull-out characterize the sample IP_BR, while a denser microstructure and a well-developed amorphous binder matrix can be observed in the samples with carbon and silica additions. An increase in homogeneity as well as minor pores and cavities is present in comparison with IP_BR. WDX analysis (EPMA) of IP_BRCS confirmed the presence of spinels (solid solutions magnetite-ulvöspinelhercynite), nepheline, or metallic iron. These minerals form with the amorphous phase a glass-ceramic-like structure, with densified, sintered particles which act as an intrinsic aggregate, partially exceeding $150 \mu \mathrm{m}$ in size, in that novel bauxite residue binder (Fig. 4).

The chemistry of the amorphous phase is characterized by an oxide ratio of $\mathrm{SiO}_{2} / \mathrm{CaO}$ of $1.1, \mathrm{SiO}_{2} / \mathrm{Al}_{2} \mathrm{O}_{3}$ of 2 , and $\mathrm{SiO}_{2} / \mathrm{FeO}$ of 7 . The binder phase shows increased ratios of $\mathrm{SiO}_{2}$ to oxides $\left(\mathrm{SiO}_{2} / \mathrm{CaO}=3.3, \mathrm{SiO}_{2} / \mathrm{Al}_{2} \mathrm{O}_{3}=4.7\right)$ with the exception of the silica-to- $\mathrm{FeO}$ ratio which decreases to 2.4. While the increasing ratio of $\mathrm{SiO}_{2} / \mathrm{CaO}$ and $\mathrm{SiO}_{2} /$ $\mathrm{Al}_{2} \mathrm{O}_{3}$ can be explained by the addition of potassium silicate (activation solution), the lower ratio of $\mathrm{SiO}_{2} / \mathrm{FeO}$ in the binder phase suggests that other phases besides the amorphous fraction dissolve during IP synthesis. For instance, it is possible that an iron-rich crystal-like spinel may partially dissolve in the used alkaline solution. Microanalysis on alkali-etched flat precursor samples, that is currently conducted, will allow deeper understanding of
Table 5 QXRD of precursor materials Pr_BR, Pr_BRC, and Pr_BRCS (estimated relative error: $10 \%)$

\begin{tabular}{|c|c|c|c|c|}
\hline \multicolumn{2}{|l|}{ Sample } & \multirow{2}{*}{$\frac{\text { Pr_BR (wt \%) }}{0}$} & \multirow{2}{*}{$\frac{\text { Pr_BRC }(\mathrm{wt} \%)}{1}$} & \multirow{2}{*}{$\frac{\text { Pr_BRCS }(\mathrm{wt} \%)}{2}$} \\
\hline Iron & $\mathrm{Fe}$ & & & \\
\hline Perovskite & $\mathrm{CaTiO}_{3}$ & 9 & 9 & 1 \\
\hline Carnegieite & $\mathrm{NaAlSiO}_{4}$ & 5 & 5 & - \\
\hline Magnetite & $\mathrm{Fe}_{3} \mathrm{O}_{4}$ & 5 & 3 & 9 \\
\hline Wüstite & $\mathrm{FeO}$ & 5 & 13 & 3 \\
\hline Quartz & $\mathrm{SiO}_{2}$ & 2 & 1 & 1 \\
\hline Hercynite & $\mathrm{FeAl}_{2} \mathrm{O}_{4}$ & 15 & 24 & 22 \\
\hline Gehlenite & $\mathrm{Ca}_{2} \mathrm{Al}_{2} \mathrm{Si}_{2} \mathrm{O}_{7}$ & 12 & 15 & 15 \\
\hline Nepheline & $\mathrm{NaAlSiO}_{4}$ & - & - & 4 \\
\hline Hematite & $\mathrm{Fe}_{2} \mathrm{O}_{3}$ & 10 & - & - \\
\hline Ulvöspinel & $\mathrm{Fe}_{2} \mathrm{TiO}_{4}$ & 2 & - & 5 \\
\hline Ferrobustamite & $\mathrm{Ca}-\mathrm{Fe}-$ silicate & 3 & - & - \\
\hline Iron silicate & $\mathrm{Fe}_{2.25} \mathrm{Si}_{0.75} \mathrm{O}_{4}$ & 12 & - & - \\
\hline Wilkinsonite & $\mathrm{Na}_{2} \mathrm{Fe}_{6} \mathrm{Si}_{6} \mathrm{O}_{20}$ & 9 & - & - \\
\hline $\begin{array}{l}\text { XRD } \\
\text { amorphous }\end{array}$ & & 10 & 30 & 39 \\
\hline
\end{tabular}


Table 6 PSD and Blaine surface of precursors

\begin{tabular}{lllll}
\hline & $\mathrm{d} 10(\mu \mathrm{m})$ & $\mathrm{d} 50(\mu \mathrm{m})$ & $\mathrm{d} 90(\mu \mathrm{m})$ & Specific surface area $\left(\mathrm{cm}^{2} / \mathrm{g}\right)$ \\
\hline Pr_BR & 0.4 & 20.3 & 160.7 & $1800 \pm 200$ \\
Pr_BRC & 0.4 & 16.0 & 142.2 & $1800 \pm 200$ \\
Pr_BRCS & 0.8 & 17.7 & 97.9 & $1850 \pm 200$ \\
\hline
\end{tabular}
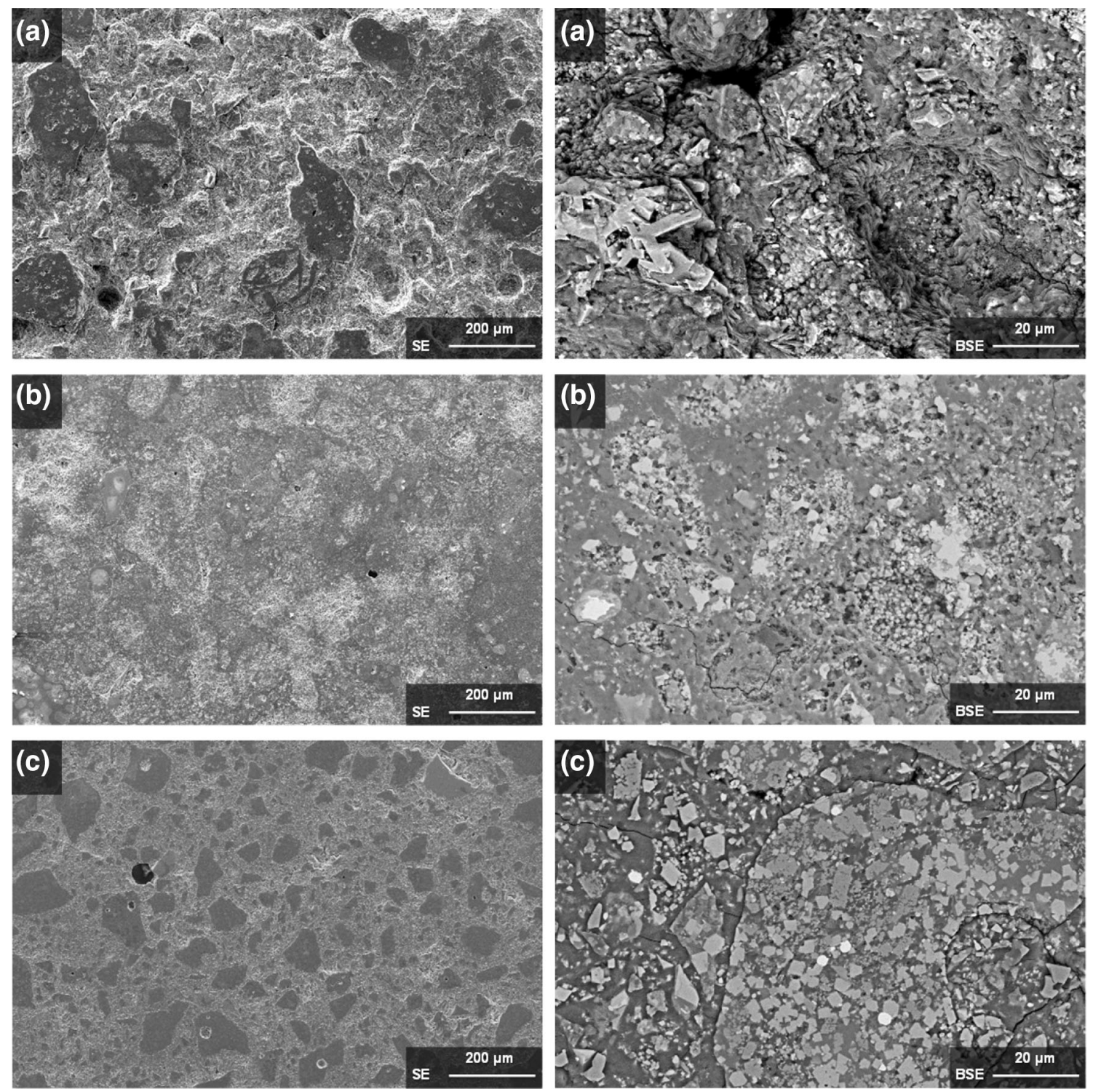

Fig. 3 Microstructure (SE and BSE images obtained by SEM analysis) of a IP_BR, b IP_BRC, and c IP_BRCS

whether crystalline phases participate in the binder formation. Nevertheless, the possibility of an artifact from the analysis due to a potential measurement of nanocrystals cannot be excluded.

FTIR absorption spectra of the precursor and the resulting inorganic polymer are compared in Fig. 5 a-c.

For the sake of clarity, only wavenumbers between 1800 and $400 \mathrm{~cm}^{-1}$ are shown. Due to the relatively complex phase assemblage, the FTIR spectra are also complex as they contain information both for the precursor materials and the formed inorganic polymers. In the wavenumber region around $500-750 \mathrm{~cm}^{-1}$ for instance, the peaks can be possibly explained by the absorption bands of Fe-containing phases, but data found in literature are controversial. Bands at 575 and $620 \mathrm{~cm}^{-1}$ in Pr_BR and IP_BR could reflect the occurrence of hematite [33], although others report hematite bands at 540 and $470 \mathrm{~cm}^{-1}$ [34]. Magnetite bands were identified around 400 and $580 \mathrm{~cm}^{-1}$ [35], while 


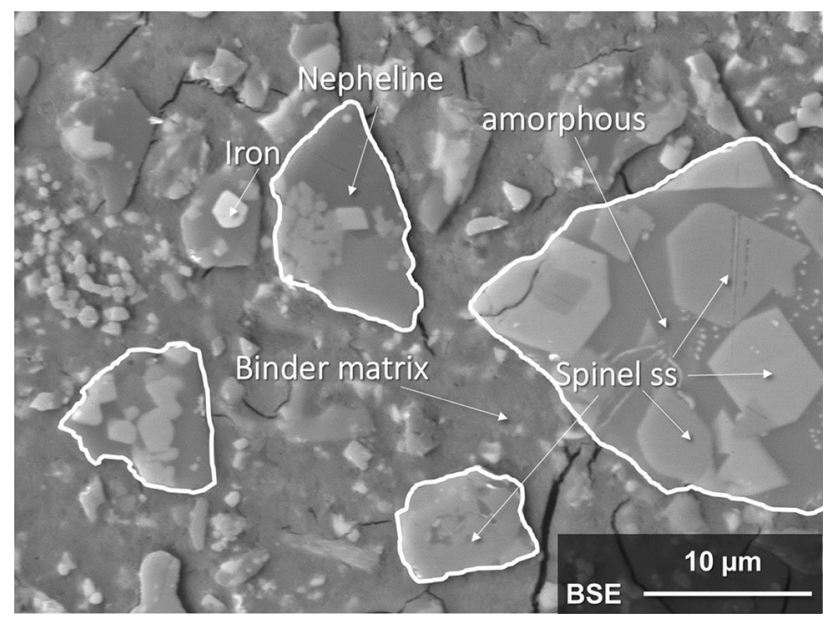

Fig. 4 Microstructure of IP_BRCS (BSE images obtained by EPMA analysis). The aggregates are highlighted with a white outline

other authors measured absorption bands of synthetic magnetite at wavenumbers of about 440 and $565 \mathrm{~cm}^{-1}$ [34]. Generally, spinels of different compositions are characterized by two main absorption peaks at about 500-550 and 690-640 $\mathrm{cm}^{-1}$ [36-38]. However, in this described range of wavenumbers, aluminosilicate phases like nepheline and also carnegieite show overlapping absorption bands at around 470, 700 and $1000 \mathrm{~cm}^{-1}$ [39]. Considering that in the present case we do not deal with stoichiometric phases but mostly with solid solutions, in addition to a Fe-containing glass, conclusions are indeed qualitative.
The focus of the investigations is on the wavenumber region around $850-1100 \mathrm{~cm}^{-1}$. For materials rich in aluminosilicates, strong asymmetric vibrations of $\mathrm{Si}-\mathrm{O}-\mathrm{T}$ $\left(\mathrm{T}=\mathrm{Al}\right.$, Si) between 1200 and $950 \mathrm{~cm}^{-1}$ [40-42], symmetric stretching vibrations of $\mathrm{Si}-\mathrm{O}-\mathrm{T}(\mathrm{T}=\mathrm{Al}, \mathrm{Si})$ at $560-800 \mathrm{~cm}^{-1}[41,43]$, as well as bending vibrations at about $470 \mathrm{~cm}^{-1}$ for $\mathrm{Si}-\mathrm{O}-\mathrm{Si}$ and $\mathrm{O}-\mathrm{Si}-\mathrm{O}$ [41-43] are reported in literature. All of these bands can be assigned to all samples. However, considering the spectra in detail, differences become more visible. While Pr_BR and Pr_BRC show a main absorption band at $971 \mathrm{~cm}^{-1}$, accompanied by three broader shoulder peaks at 863,908 , and $1020 \mathrm{~cm}^{-1}$, the absorption spectrum of Pr_BRCS between 850 and $1100 \mathrm{~cm}^{-1}$ is characterized by two distinguishable peaks at 978 and $908 \mathrm{~cm}^{-1}$ and broader shoulder peaks at 860 and $1070 \mathrm{~cm}^{-1}$. Pisciella and Pelino investigated the distortion of silica networks by analyzing Fe-rich glasses. They reported a shift to lower wavenumbers in comparison with silica glass due to the iron incorporation in the network [44]. This and also the incorporation of other network modifiers and network breakers seem plausible for the investigated samples in view of the chemical composition.

After activation of the precursors, slight shifts are visible in the FTIR spectra. All inorganic polymer spectra differ between 800 and $1100 \mathrm{~cm}^{-1}$ from the precursors in terms of generally higher absorption, which indicates the formation of new reaction products, as well as shifts and changed intensity ratios of absorption peaks. IP_BR demonstrates a
Fig. 5 FTIR spectra of precursor materials (black dotted line) and inorganic polymer (red): a BR, b BRC, and $\mathbf{c}$ BRCS

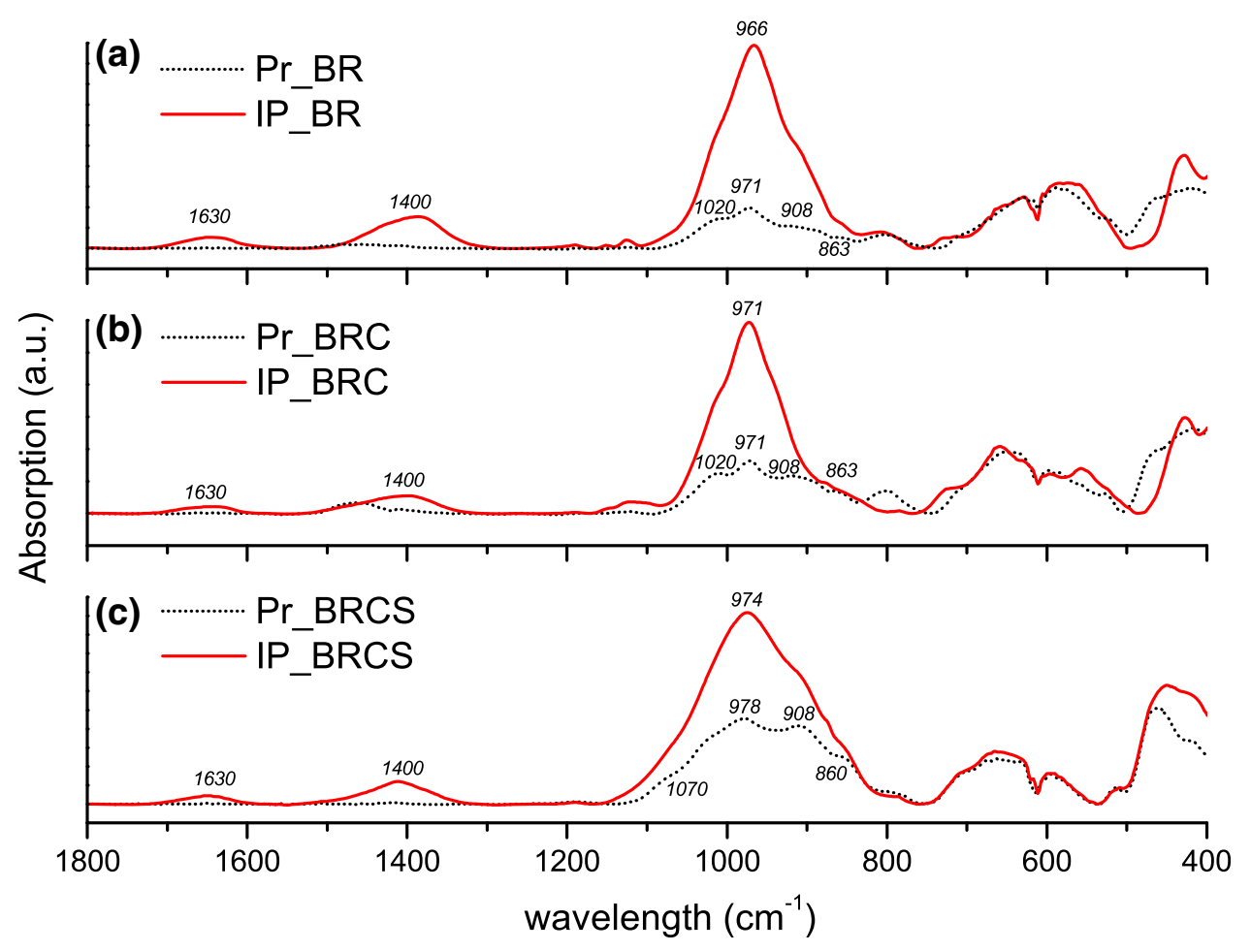


Table 7 Compressive and flexural strengths of synthesized inorganic polymers, cured at $60{ }^{\circ} \mathrm{C}$ for $72 \mathrm{~h}$

\begin{tabular}{lll}
\hline Mix & Compressive strength (MPa) & Flexural strength (MPa) \\
\hline IP_BR & $13.4 \pm 0.4$ & 4.2 \\
IP_BRC & $19.7 \pm 1.1$ & 5.5 \\
IP_BRCS & $43.5 \pm 0.5$ & 9.8 \\
\hline
\end{tabular}

slight shift of the main band of 971-966 $\mathrm{cm}^{-1}$, in comparison with Pr_BR. For IP_BRCS, the main absorption peak shifts from 978 to $974 \mathrm{~cm}^{-1}$ and relatively increases more distinctly than the absorption peak at $898 \mathrm{~cm}^{-1}$ (in precursor $908 \mathrm{~cm}^{-1}$ ) compared to the precursor material. The shifts indicate the substitution of $\mathrm{Si}$ in the $\mathrm{Si}-\mathrm{O}-\mathrm{Si}$ stretching vibration, which shows the most intensive peak at $1100 \mathrm{~cm}^{-1}$ [45], by other network formers like $\mathrm{Al}$ and the formation of a new reaction product $[46,47]$. An incorporation of network breakers like $\mathrm{Fe}^{2+}$ and $\mathrm{Ca}^{2+}$ is also reported as a possible reason of a shift of the bands compared to the $\mathrm{Si}-\mathrm{O}-\mathrm{Si}$ peak $[48,49]$ as well as the oxidation of the ferrous iron released by the dissolution of the slag to ferric iron in the formed IP binder [50]. For all inorganic polymer samples, bands at $1630 \mathrm{~cm}^{-1}$ - corresponding to the $\mathrm{O}-\mathrm{H}$ bending of $\mathrm{H}_{2} \mathrm{O}$ molecules indicating the incorporation of water [51] - and $1400 \mathrm{~cm}^{-1}$ —indicating the atmospheric carbonation of the inorganic polymer specimens (asymmetric stretching vibrations of $\mathrm{O}-\mathrm{C}-\mathrm{O}$ ) - occur.

The mechanical properties of the three sample types are listed in Table 7. It is evident that the compressive and flexural strengths are increasing from IP_BR and IP_BRC to IP_BRCS. As seen in the microstructural analysis, the higher quantity of available silica seems to promote the formation of glass-sintered and/or glass-ceramic (assuming that crystal precipitation took place during solidification, like in a petrurgic process) particles that function as aggregates, and in addition contributes to a denser and stronger binder phase. The reasoning behind this change should be primarily attributed to the role of silica during the heating cycle. Based on the data, it is verified that more amorphous phase is formed, and finally remains during cooling, whereas the chemistry of that phase is also different compared to the other bauxite residue blends. Thus, the total amount and the specific composition will eventually affect the dissolution kinetics and will finally influence both the microstructure and properties. For the most promising sample IP_BRCS, compressive strength was tested additionally after 28 days for samples cured at room temperature. Compressive strengths of $43.5 \pm 7.5 \mathrm{MPa}$ were measured, suggesting that the curing at $60{ }^{\circ} \mathrm{C}$ results in the final strengths of the products already at 3 days.

\section{A Possible Industrial Implementation of the Process}

The starting point of an industrial implementation of the process developed herein could be the addition of an easily available silica source, e.g., sand, and a carbon source, e.g., lignite, to the fresh BR slurry. This new blend slurry is filter-pressed to separate the compositionally modified cake from the alkaline liquor. The latter can be used as an alkaline activator for the inorganic polymer precursor by

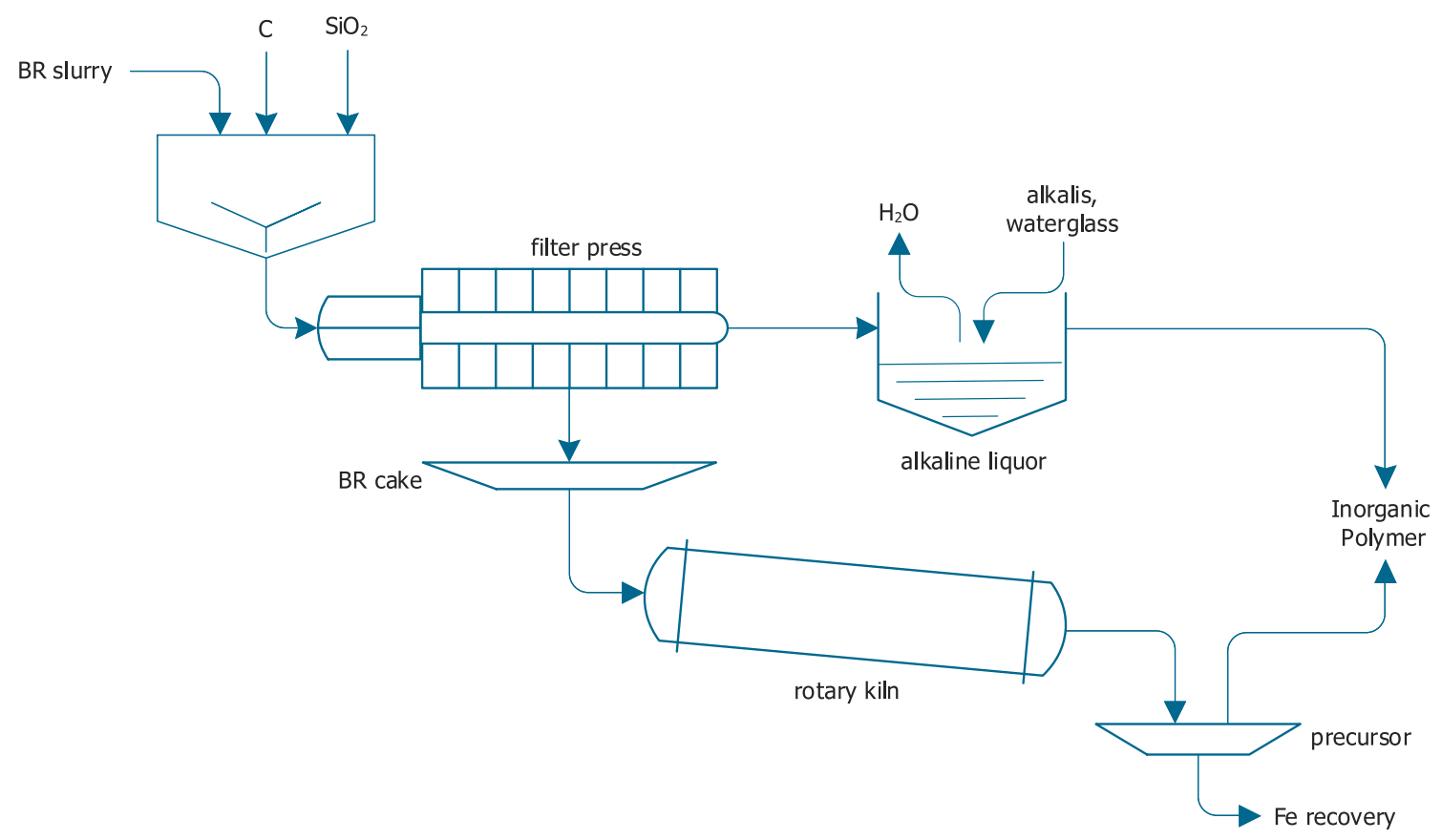

Fig. 6 Possible implementation of the described process for valorization of bauxite residue in inorganic polymers 
adjusting the alkalinity of the liquor, e.g., by partially evaporating water or by adding alkalis or waterglass. A reactive, partially vitrified precursor is produced in the following step by feeding the pressed, modified cake in an existing rotary kiln, used for dehydration of alumina hydroxides, or a sinter bed used for iron sintering. The formation of magnetic iron phases like metallic iron or magnetite during the heat treatment leads to the possible recovery of $\mathrm{Fe}$ in an intermediate step applying magnetic separation techniques. The remaining precursor, depending on the mineralogy, is enriched in a $\mathrm{Si}, \mathrm{Al}, \mathrm{Ca}, \mathrm{Na}$, and $\mathrm{Ti}$ glass and serves in combination with the recycled alkaline liquor as a raw material for the synthesis of inorganic polymers. With the described process, a complete in-house valorization of bauxite residue can be achieved and applications like tiles, for floors, pavements, or roofs seem conceivable. The scheme is shown in Fig. 6.

Nevertheless, the main focus of this study was on the proof-of-concept of the described process of valorizing BR toward inorganic polymer binders. The aspects of environmental footprint and of economic assessment of the process are currently investigated and results will appear soon. In this forthcoming study, a range of options are also evaluated, e.g., comparison of heat treatment installations, aiming to define the most favorable operating window.

\section{Conclusion}

In this work, a new process is suggested where BR is chemically and thermally modified and transformed from an unwanted residue into a resource for a valuable, alternative building material. An industrial application and scale-up seem feasible and realistic, since only minor additions of carbon and silica are required, and since the production-relevant infrastructure which is a filter press and rotary kilns may already exist within the alumina refinery premises. A mix of $88.6 \mathrm{wt} \% \mathrm{BR}, 1.4 \mathrm{wt} \% \mathrm{C}$, and $10.0 \mathrm{wt} \% \mathrm{SiO}_{2}$ was proved to give the best results in terms of properties, exceeding $40 \mathrm{MPa}$ in compressive strength. This is attributed to the increased quantity of a silica-rich amorphous, reactive phase. This approach can be seen as an add-on to the existing Bayer process and has the potential to transform it into an integrated zero-waste processing scheme.

Acknowledgments The research leading to these results has received funding from the European Community's Horizon 2020 Programme (H2020/2014-2019) under Grant Agreement No. 636876 (MSCAETN REDMUD). This publication reflects only the author's view, exempting the Community from any liability. Project website: http:// www.etn.redmud.org.

\section{References}

1. Kumar S, Kumar R, Bandopadhyay A (2006) Innovative methodologies for the utilisation of wastes from metallurgical and allied industries. Resour Conserv Recy 48(4):301-314. doi:10.1016/j.resconrec.2006.03.003

2. Klauber C, Gräfe M, Power G (2011) Bauxite residue issues: II. Options for residue utilization. Hydrometallurgy 108(1-2):11-32. doi:10.1016/j.hydromet.2011.02.007

3. Gräfe M, Power G, Klauber C (2009) Review of bauxite residue alkalinity and associated chemistry. CSIRO Document DMR3610, Project ATF-06-3: "Management of Bauxite Residues". Department of Resources, Energy and Tourism (DRET)

4. Pontikes Y, Rathossi C, Nikolopoulos P, Angelopoulos GN, Jayaseelan DD, Lee WE (2009) Effect of firing temperature and atmosphere on sintering of ceramics made from Bayer process bauxite residue. Ceram Int 35(1):401-407. doi:10.1016/j.cer amint.2007.11.013

5. Pontikes Y, Angelopoulos GN (2009) Effect of firing atmosphere and soaking time on heavy clay ceramics with addition of Bayer's process bauxite residue. Adv Appl Ceram 108(1):50-56. doi:10. 1179/174367509X344999

6. Binnemans K, Jones PT, Blanpain B, van Gerven T, Pontikes Y (2015) Towards zero-waste valorisation of rare-earth-containing industrial process residues: a critical review. J Clean Prod 99:17-38. doi:10.1016/j.jclepro.2015.02.089

7. Borra CR, Pontikes Y, Binnemans K, van Gerven T (2015) Leaching of rare earths from bauxite residue (red mud). Min Eng 76:20-27. doi:10.1016/j.mineng.2015.01.005

8. Pontikes Y, Angelopoulos GN (2013) Bauxite residue in cement and cementitious applications: current status and a possible way forward. Resour Conserv Recy 73:53-63. doi:10.1016/j.rescon rec.2013.01.005

9. Lloyd RR, Provis JL, van Deventer JSJ (2012) Acid resistance of inorganic polymer binders. 1. Corrosion rate. Mater Struct 45(1-2):1-14. doi:10.1617/s11527-011-9744-7

10. Barbosa VF, MacKenzie KJ (2003) Thermal behaviour of inorganic geopolymers and composites derived from sodium polysialate. Mater Res Bull 38(2):319-331. doi:10.1016/S00255408(02)01022-X

11. Duxson P, Provis JL, Lukey GC, van Deventer JSJ (2007) The role of inorganic polymer technology in the development of 'green concrete'. Cem Concr Res 37(12):1590-1597. doi:10. 1016/j.cemconres.2007.08.018

12. Lee W, van Deventer JSJ (2002) The effect of ionic contaminants on the early-age properties of alkali-activated fly ash-based cements. Cem Concr Res 32(4):577-584. doi:10.1016/S00088846(01)00724-4

13. McLellan BC, Williams RP, Lay J, van Riessen A, Corder GD (2011) Costs and carbon emissions for geopolymer pastes in comparison to ordinary portland cement. J Clean Prod 19(9-10):1080-1090. doi:10.1016/j.jclepro.2011.02.010

14. Mellado A, Catalán C, Bouzón N, Borrachero MV, Monzó JM, Payá J (2014) Carbon footprint of geopolymeric mortar: study of the contribution of the alkaline activating solution and assessment of an alternative route. RSC $\operatorname{Adv} 4(45): 23846$. doi:10.1039/ c4ra03375b

15. Davidovits J (2011) Geopolymer chemistry and applications, 3rd edn. Institut Géopolymère, Saint-Quentin

16. van Deventer JSJ, Provis JL, Duxson P, Brice DG (2010) Chemical research and climate change as drivers in the commercial adoption of alkali activated materials. Waste Biomass Valor 1(1):145-155. doi:10.1007/s12649-010-9015-9 
17. Dimas DD, Giannopoulou IP, Panias D (2009) Utilization of alumina red mud for synthesis of inorganic polymeric materials. Miner Process Extr Metall Rev 30(3):211-239. doi:10.1080/ 08827500802498199

18. He J, Jie Y, Zhang J, Yu Y, Zhang G (2013) Synthesis and characterization of red mud and rice husk ash-based geopolymer composites. Cem Concr Comp 37:108-118. doi:10.1016/j.cem concomp.2012.11.010

19. Ye N, Yang J, Ke X, Zhu J, Li Y, Xiang C, Wang H, Li L, Xiao B, Biernacki J (2014) Synthesis and characterization of geopolymer from Bayer red mud with thermal pretreatment. J Am Ceram Soc 97(5):1652-1660. doi:10.1111/jace.12840

20. Badanoiu AI, Saadi Al, Abood Taha H, Stoleriu S, Voicu G (2015) Preparation and characterization of foamed geopolymers from waste glass and red mud. Constr Build Mater 84:284-293. doi:10.1016/j.conbuildmat.2015.03.004

21. Ke X, Bernal SA, Ye N, Provis JL, Yang J, Biernacki J (2015) One-part geopolymers based on thermally treated red mud/NaOH blends. J Am Ceram Soc 98(1):5-11. doi:10.1111/jace.13231

22. Hairi SNM, Jameson GNL, Rogers JJ, MacKenzie KJD (2015) Synthesis and properties of inorganic polymers (geopolymers) derived from Bayer process residue (red mud) and bauxite. J Mater Sci 50(23):7713-7724. doi:10.1007/s10853-015-9338-9

23. Onisei S, Lesage K, Blanpain B, Pontikes Y, Struble L (2015) Early age microstructural transformations of an inorganic polymer made of fayalite slag. J Am Ceram Soc. doi:10.1111/jace. 13548

24. Onisei S, Pontikes Y, van Gerven T, Angelopoulos GN, Velea T, Predica V, Moldovan P (2012) Synthesis of inorganic polymers using fly ash and primary lead slag. J Hazard Mater 205-206:101-110. doi:10.1016/j.jhazmat.2011.12.039

25. Sakkas K, Nomikos P, Sofianos A, Panias D (2014) Utilisation of FeNi-slag for the production of inorganic polymeric materials for construction or for passive fire protection. Waste Biomass Valor 5(3):403-410. doi:10.1007/s12649-013-9278-z

26. Komnitsas K, Zaharaki D, Perdikatsis V (2007) Geopolymerisation of low calcium ferronickel slags. J Mater Sci 42(9):3073-3082. doi:10.1007/s10853-006-0529-2

27. Pontikes Y, Machiels L, Onisei S, Pandelaers L, Geysen D, Jones PT, Blanpain B (2013) Slags with a high Al and Fe content as precursors for inorganic polymers. Appl Clay Sci 73:93-102. doi:10.1016/j.clay.2012.09.020

28. Coelho AA (2004) TOPAS-Academic; A Computer Programme for Rietveld Analysis. http://www.topas-academic.net/

29. Belsky A, Hellenbrandt M, Karen VL, Luksch P (2002) New developments in the Inorganic Crystal Structure Database (ICSD): accessibility in support of materials research and design. Acta Cryst Sect B 58(3):364-369. doi:10.1107/ S0108768102006948

30. Bale CW, Bélisle E, Chartrand P, Decterov SA, Eriksson G, Hack K, Jung IH, Kang YB, Melançon J, Pelton AD, Robelin C, Petersen S (2009) FactSage thermochemical software and databases-recent developments. Calphad 33:295-311. http://www. factsage.com

31. Rivas-Mercury JM, Pena P, de Aza AH, Turrillas X (2008) Dehydration of $\mathrm{Ca}_{3} \mathrm{Al}_{2}\left(\mathrm{SiO}_{4}\right)_{y}(\mathrm{OH})_{4(3-y)}(0<y<0.176)$ studied by neutron thermodiffractometry. J Eur Ceram Soc 28(9):1737-1748. doi:10.1016/j.jeurceramsoc.2007.12.038

32. Hassan I (2006) Cancrinite: crystal structure, phase transitions, and dehydration behavior with temperature. Am Mineral 91(7):1117-1124. doi:10.2138/am.2006.2013

33. Namduri H, Nasrazadani S (2008) Quantitative analysis of iron oxides using Fourier transform infrared spectrophotometry. Corros Sci 50(9):2493-2497. doi:10.1016/j.corsci.2008.06.034

34. Nasrazadani S, Namduri H (2006) Study of phase transformation in iron oxides using laser induced breakdown spectroscopy.
Spectrochim Act B 61(5):565-571. doi:10.1016/j.sab.2006.04. 001

35. Cornell RM, Schwertmann U (2003) The Iron oxides: structure, properties, reactions, occurrences and uses, 2nd, completely revised and extended edn. Wiley, Weinheim

36. Zhang P, Li X, Zhao Q, Liu S (2011) Synthesis and optical property of one-dimensional spinel $\mathrm{ZnMn}_{2} \mathrm{O}_{4}$ nanorods. Nanoscale Res Lett 6(1):323. doi:10.1186/1556-276X-6-323

37. Richardson TJ, Wen SJ, Strichel KA, Ross PN, Cairns EJ (1997) FTIR spectroscopy of metal oxide insertion materials: analysis of $\mathrm{Li}_{\mathrm{x}} \mathrm{Mn}_{2} \mathrm{O}_{4}$ spinel electrodes. Mater Res Bull 32(5):609-618. doi:10.1016/S0025-5408(97)00022-6

38. Fu P, Lu W, Lei W, Wu K, Xu Y, Wu J (2013) Thermal stability and microstructure characterization of $\mathrm{MgAl}_{2} \mathrm{O}_{4}$ nanoparticles synthesized by reverse microemulsion method. Mater Res 16(4):844-849. doi:10.1590/S1516-14392013005000062

39. Markovic S, Dondur V, Dimitrijevic R (2003) FTIR spectroscopy of framework aluminosilicate structures: carnegieite and pure sodium nepheline. J Mol Struct 654(1-3):223-234. doi:10.1016/ S0022-2860(03)00249-7

40. Ghosh SN (1978) Infra-red spectra of some selected minerals, rocks and products. J Mater Sci 13(9):1877-1886. doi:10.1007/ BF00552894

41. Farmer VC (1974) The infrared spectra of minerals. Mineralogical Society of Great Britain and Ireland, London

42. Gadsden JA (1975) Infrared spectra of minerals and related inorganic compounds. Butterworth, London

43. Poe BT, McMillan PF, Angell CA, Sato RK (1992) Al and Si coordination in $\mathrm{SiO}_{2}-\mathrm{Al}_{2} \mathrm{O}_{3}$ glasses and liquids: a study by NMR and IR spectroscopy and MD simulations. Chem Geol 96(3-4):333-349. doi:10.1016/0009-2541(92)90063-B

44. Pisciella P, Pelino M (2005) FTIR spectroscopy investigation of the crystallisation process in an iron rich glass. J Eur Ceram Soc 25(11):1855-1861. doi:10.1016/j.jeurceramsoc.2004.06.012

45. Devine R (1993) Ion implantation- and radiation-induced structural modifications in amorphous $\mathrm{SiO}_{2}$. J Non-Cryst Solids 152(1):50-58. doi:10.1016/0022-3093(93)90443-2

46. Rahier H, Wastiels J, Biesemans M, Willlem R, van Assche G, van Mele B (2007) Reaction mechanism, kinetics and high temperature transformations of geopolymers. J Mater Sci 42(9):2982-2996. doi:10.1007/s10853-006-0568-8

47. Rees CA, Provis JL, Lukey GC, van Deventer JSJ (2007) Attenuated total reflectance fourier transform infrared analysis of fly ash geopolymer gel aging. Langmuir 23(15):8170-8179. doi:10.1021/la700713g

48. Mysen BO, Virgo D, Neumann ER, Seifert FA (1985) Redox equilibria and the structural states of ferric and ferrous iron in melts in the system $\mathrm{CaO}-\mathrm{MgO}-\mathrm{Al}_{2} \mathrm{O}_{3}-\mathrm{SiO}_{2}-\mathrm{FeO}$ : relationships between redox equilibria, melt structure and liquidus phase equilibria. Am Mineral 70(3-4):317-331

49. Serra J, González P, Liste S, Serra C, Chiussi S, León B, PérezAmor M, Ylänen HO, Hupa M (2003) FTIR and XPS studies of bioactive silica based glasses. J Non-Cryst Solids 332(1-3):20-27. doi:10.1016/j.jnoncrysol.2003.09.013

50. Bordiga S, Buzzoni R, Geobaldo F, Lamberti C, Giamello E, Zecchina A, Leofanti G, Petrini G, Tozzola G, Vlaic G (1996) Structure and reactivity of framework and extraframework iron in Fe-Silicalite as investigated by spectroscopic and physicochemical methods. J Catal 158(2):486-501. doi:10.1006/jcat.1996. 0048

51. Lappi SE, Smith B, Franzen S (2004) Infrared spectra of $\mathrm{H}_{(2)}^{16} \mathrm{O}$, $\mathrm{H}_{(2)}^{18} \mathrm{O}$ and $\mathrm{D}_{(2)} \mathrm{O}$ in the liquid phase by single-pass attenuated total internal reflection spectroscopy. Spectrochim Acta A 60(11):2611-2619. doi:10.1016/j.saa.2003.12.042 